\title{
IMPACTS FROM WINTER-EARLY SPRING ELK GRAZING IN FOOTHILLS ROUGH FESCUE GRASSLAND
}

\author{
Tanya M. Thrift ${ }^{1}$, Tracy K. Mosley², and Jeffrey C. Mosley ${ }^{3}$
}

\begin{abstract}
AвSTRACT.-Foothills rough fescue (Festuca campestris) grasslands provide important foraging habitat for wildlife and livestock in the northwestern United States and southwestern Canada. Foothills rough fescue is sensitive to grazing during late spring-early summer but is believed to be more tolerant of grazing during winter-early spring. We evaluated vegetation and soil impacts from long-term winter-early spring grazing at 2 intensities (HG = heavy grazing, $\mathrm{LG}=$ light grazing). We studied a foothills rough fescue grassland in west central Montana, USA, that had been grazed almost exclusively by Rocky Mountain elk (Cervus elaphus nelsoni) during winter-early spring for 58 years. Foothills rough fescue tolerated LG but not HG, whereas bluebunch wheatgrass (Pseudoroegneria spicata) and Idaho fescue (Festuca idahoensis) did not tolerate either LG or HG. Decreased productivity of foothills rough fescue in HG was accompanied by decreased herbaceous ground cover and increased abundance of the invasive dense clubmoss (Selaginella densa). Soil nutrient status (OM, C, N, C:N ratio) did not differ between HG and LG; however, soil bulk density was $18 \%$ greater in HG, and the Ah horizon was $20 \%$ thinner in HG. Overall, our results indicate that long-term elk grazing during winter-early spring degraded this terrestrial ecosystem, and we conclude that periodic rest from ungulate grazing during winter-early spring is necessary to sustain foothills rough fescue grasslands.
\end{abstract}

RESUMEN.-Los prados de Festuca campestris en las laderas montañosas constituyen un hábitat muy importante para la búsqueda de alimento de la fauna silvestre y el ganado en el noroeste de los Estados Unidos y el sudoeste de Canadá. Los prados de F. campestris son menos resistentes al pastoreo durante el período de finales de la primavera y principios del verano, sin embargo se cree que son más resistentes en invierno y al inicio de la primavera. Evaluamos el impacto del suelo y la vegetación del pastoreo a largo plazo durante el invierno y al inicio de la primavera, con dos intensidades $(\mathrm{HG}=$ gran pastoreo; $\mathrm{LG}=$ pastoreo ligero). Estudiamos un prado en las laderas montañosas en la parte central-oeste de Montana, EE. UU., en el cual el Alce de las Montañas Rocallosas (Cervus elaphus nelsoni) fue casi la única especie que se registró en el pastoreo, en el invierno y al inicio de la primavera, durante 58 años. En este prado de F. campestris se realizó el LG, pero no se pudo realizar el HG, mientras que Pseudoroegneria spicata y Festuca idahoensis de Idaho no toleraron ni el LG ni el HG. Observamos una baja productividad del prado de F. campestris en las laderas montañosas en el HG, un bajo nivel de cobertura herbácea del suelo y un aumento de Selaginella densa, una especie invasora. La concentración de nutrientes del suelo (índice OM, C, N, C:N) no fue diferente entre el HG y el LG, pero la densidad del suelo fue $18 \%$ mayor en HG y el horizonte Ah/A fue $20 \%$ más fino en el HG. Nuestros resultados generales indican que el pastoreo del alce a largo plazo durante el invierno y el inicio de la primavera degradó este ecosistema terrestre y llegamos a la conclusión de que es necesario un descanso periódico del pastoreo de ungulados durante el invierno y el inicio de la primavera para conservar los prados de F. campestris en las laderas montañosas en buen estado.

Foothills rough fescue (Festuca campestris) grasslands provide important wildlife and livestock foraging habitat in foothills and mountains of the northwestern United States and southwestern Canada. Potential natural plant communities of these grasslands are dominated by foothills rough fescue, a perennial bunchgrass. Bluebunch wheatgrass (Pseudoroegneria spicata) and Idaho fescue (Festuca idahoensis) often co-occur with foothills rough fescue in western Montana and southern British Columbia (Tisdale 1947, Mueggler and Stewart 1980), whereas Parry oatgrass (Danthonia parryi) and Idaho fescue often co-occur with foothills rough fescue in southern Alberta (Moss and Campbell 1947, Looman 1969).

The common name for foothills rough fescue was previously buffalo bunchgrass (USDA-FS 1937, Johnston and MacDonald 1967) because it was the primary winter forage for bison (Bison bison) on foothill grasslands in the Northern Rocky Mountains (Fryxell 1928, Johnston and MacDonald 1967, Dormaar and Willms 1990). Foothills rough fescue is believed to have evolved with heavy grazing by bison during winter, which belief fostered

\footnotetext{
${ }^{1}$ Bureau of Land Management, Bruneau Field Office, 3948 Development Ave., Boise, ID 83705.

${ }^{2}$ Corresponding author. Montana State University Extension, 119 South 3rd St., Livingston, MT 59047. E-mail: tmosley@montana.edu

${ }^{3}$ Department of Animal and Range Sciences, Montana State University, Bozeman, MT 59717.
} 
misconceptions that foothills rough fescue was tolerant of heavy grazing in other seasons (Johnston and MacDonald 1967). Several studies have documented that foothills rough fescue does not tolerate heavy grazing during late spring or early summer (i.e., during the boot or inflorescence emergence stage; Johnston et al. 1971, McLean and Wikeem 1985b, Willms et al. 1985, 1988, Willms 1991, Willms and Quinton 1995). Co-occurring bluebunch wheatgrass and Idaho fescue also do not tolerate heavy grazing during late spring or early summer (McLean and Wikeem 1985a, Willms et al. 1988, Brewer et al. 2007).

In contrast, light or moderate intensities of defoliation in late spring or early summer are sustainable for foothills rough fescue and co-occurring bluebunch wheatgrass and Idaho fescue (Johnston et al. 1971, McLean and Wikeem 1985a, 1985b, Willms et al. 1985, 1988, Willms 1991, Willms and Quinton 1995, Brewer et al. 2007), provided that light or moderate defoliation in late spring or early summer does not reoccur more frequently than 2 successive years (Brewer et al. 2007).

Ungulate grazing during winter plant dormancy or early spring is generally believed to impact foothills rough fescue grasslands much less than grazing later in the growing season (McLean and Tisdale 1972, Brewer et al. 2007). However, sustainable thresholds of winter-early spring grazing intensity and frequency have not been established for foothills rough fescue grasslands. We evaluated vegetation and soil effects of long-term winterearly spring grazing at 2 intensities $(\mathrm{HG}=$ heavy grazing, $L G=$ light grazing). Our study area was a foothills rough fescue grassland in west central Montana, USA, that had been grazed almost exclusively by Rocky Mountain elk (Cervus elaphus nelsoni) during winterearly spring for 58 years. We hypothesized that vegetation, ground cover, and soils had been sustained by LG but not HG.

\section{Methods}

\section{Study Area}

We sampled vegetation, ground cover, and soils within the Sun River Wildlife Management Area (SRWMA) in west central Montana. The SRWMA is about $8100 \mathrm{ha}$, located $15 \mathrm{~km}$ northwest of Augusta, Montana, and managed by the Montana Department of Fish, Wildlife and Parks. The SRWMA was established in 1947 to protect elk winter range, and with the exception of an incidental few white-tailed deer (Odocoileus virginianus), mule deer (Odocoileus hemionus), and pronghorns (Antilocapra americana), the SRWMA has been grazed exclusively by elk during winter-early spring since late in 1947 when livestock grazing was eliminated (Jourdonnais and Bedunah 1990). This study area provided a unique opportunity to evaluate the impacts of long-term grazing during winter-early spring, without confounding effects from grazing during late spring, summer, or fall. Elk numbers have fluctuated through time, but from 1965 to present, about 2150 elk have grazed the study area annually from mid-November through April, with very few elk remaining until mid-May (Knight 1970, Picton and Picton 1975; Q. Kujala and G. Taylor, Montana Fish, Wildlife and Parks, personal communication).

Annual precipitation at the SRWMA averages $341 \mathrm{~mm}$, with 58\% received during April-July (Western Regional Climate Center 2005). Our study sites were located within the needle and thread (Hesperostipa comata) phase of the rough fescue/bluebunch wheatgrass habitat type (Mueggler and Stewart 1980). The soil type was classified as Beanlake-Winspect Stony Loams 4\%-25\% Slope (USDA-NRCS 2003), and the ecological site was Limy in the 330 to $483-\mathrm{mm}$ precipitation zone within the Northern Rocky Mountains Foothills-North Major Land Resource Area (USDA-NRCS in press). Dominant graminoids on our study sites included rough fescue, bluebunch wheatgrass, Idaho fescue, needle and thread, prairie junegrass (Koeleria macrantha), and threadleaf sedge (Carex filifolia). Common forbs included dotted blazing star (Liatris punctata), hairy golden aster (Heterotheca villosa), fringed sagewort (Artemisia frigida), and wild onion (Allium sp.). Shrubs were scarce on our study sites, but shrub species present included shrubby cinquefoil (Potentilla fruticosa), creeping juniper (Juniperus horizontalis), and snowberry (Symphoricarpos albus).

Study sites were randomly selected using GIS (4 LG sites and 4 HG sites). Montana Department of Fish, Wildlife and Parks' elk forage use data from 1967 to 2003 were used to stratify the grassland according to LG and HG. Long-term elk grazing use of foothills 
rough fescue averaged 30\% in LG sites and $68 \%$ in HG sites. Elk grazing intensities across the study area were very consistent among years due to distances from a county road that received moderate vehicle traffic during winter-early spring. Grazing intensity was light near the road and heavy far from the road. All 8 sites had the same slope $(7.5 \%)$, aspect (northeastern), elevation $(1350 \mathrm{~m})$, and soils (Beanlake-Winspect Stony Loams 4\%-25\% Slope). All 4 LG sites were separated from each other by at least $400 \mathrm{~m}$. All $4 \mathrm{HG}$ sites also were separated from each other by at least $400 \mathrm{~m}$, and the minimum distance separating LG from HG sites was $4500 \mathrm{~m}$. A soil pit was dug near the center of each study site, and soils on all 8 sites were classified to confirm that they were Beanlake-Winspect Stony Loams 4\%-25\% Slope (USDA-NRCS 2003). Similarly, the habitat type phase and ecological site (i.e., potential natural plant community with similar potential plant productivity) of each study site were identified with a dichotomous key to confirm that all 8 study sites were within the same habitat type phase (i.e., needle and thread phase of the rough fescue/bluebunch wheatgrass habitat type; Mueggler and Stewart 1980) and the same ecological site (i.e., Limy in the $330-483 \mathrm{~mm}$ precipitation zone within the Northern Rocky Mountains Foothills-North Major Land Resource Area; USDANRCS in press). Our 8 study sites differed only in their long-term elk grazing intensity during winter-early spring (LG vs. HG).

Data Collection and Laboratory Analyses

Vegetation was sampled in July 2004 and sampled again in July 2005 to account for temporal variation in plant growth. Soils were sampled in July 2005 only. Three 60 -m transects were established at each of the 8 study sites.

Vigor of foothills rough fescue, Idaho fescue, and bluebunch wheatgrass plants was quantified by measuring average leaf height (Mueggler 1975), basal diameter (Cook and Stubbendieck 1986), and percentage of filled florets (Patton et al. 1988). Plant vigor variables were measured on the nearest foothills rough fescue, bluebunch wheatgrass, and Idaho fescue plants at 3-m intervals along each $60-\mathrm{m}$ transect $(n=60$ plants/grass species/study site/year). Average leaf height was sampled by measuring the average height of current year's leaves in their natural position, with measurements made from the center of plant crowns (USDA and USDI 1996). Basal diameter of individual plants was sampled by measuring the distance across the plant crown at the widest point. Every seedhead was collected from each of the sampled plants. Seedheads were returned to the laboratory and the percentage of filled florets was determined by visually inspecting the florets on a fluorescent light table (Patton et al. 1988).

Vegetative canopy cover, by species, was sampled using a modified Daubenmire canopy coverage method with 7 cover classes (Daubenmire 1959, Bailey and Poulton 1968). A $20 \times$ $50-\mathrm{cm}$ quadrat was placed at $20-\mathrm{m}$ intervals along each transect at different locations each year ( $n=9$ quadrats/study site/year). Plant species composition of each study site was determined by dividing total percentage canopy cover of each species by total percentage canopy cover of all species on the site and then multiplying by 100 .

Herbaceous plant yield was measured by clipping current-year's growth to ground level within three $50 \times 50$-cm quadrats per transect placed at different locations along the transects each year $(n=9$ quadrats/study site/year). At 20-m intervals along each transect, vegetation was clipped and separated into graminoids and forbs. Clipped samples were returned to the laboratory and weighed after oven-drying at $55^{\circ} \mathrm{C}$ for $48 \mathrm{~h}$.

Bare ground and ground cover of litter, graminoids + forbs, dense clubmoss, rock $(>2$ $\mathrm{cm}$ diameter), and gravel $(0.5-2 \mathrm{~cm}$ diameter) were sampled using the point-intercept method (USDA and USDI 1996). Ground cover was sampled at 6 points on a $20 \times 50$ $\mathrm{cm}$ quadrat frame, with quadrats positioned at 20 -m intervals along each of the three $60-\mathrm{m}$ transects ( $n=54$ points/study site/year).

Soil samples were collected at 20 -m intervals along each transect $(n=9$ samples/study site). For soil nutrient status, soil samples were extracted from the Ah horizon, excluding the vegetation and litter on the soil surface, using a $2.54-\mathrm{cm}$ diameter soil probe. Soil nutrient samples were returned to the laboratory and analyzed for soil organic matter (OM), soil carbon $(\mathrm{C})$, soil nitrogen $(\mathrm{N})$, and $\mathrm{C}: \mathrm{N}$ ratio. Soil $\mathrm{C}$ and $\mathrm{N}$ were determined using the Carbo-Erba combustion method (AOAC 1997). Soil OM was determined using a modified 
Walkley-Black method (Nelson and Sommers 1982). Soil bulk density was determined by inserting a metal ring $(7.62-\mathrm{cm}$ depth $\times 7.62$ $\mathrm{cm}$ diameter) into the Ah soil horizon until the top of the ring was level with the soil surface. Contents of the ring were extracted from the soil, placed in sealed containers, returned to the laboratory, and weighed after oven-drying at $105{ }^{\circ} \mathrm{C}$ for $48 \mathrm{~h}$. Bulk density was calculated by dividing the dry soil mass by the soil volume (Blake and Hartge 1986). Finally, thickness of the Ah horizon was determined by digging a soil pit near the center of each study site, visually determining the extent of the Ah horizon, and measuring its thickness to the nearest centimeter.

\section{Data Analysis}

The study design was observational (Cochran 1983, Eberhardt and Thomas 1991) because we did not control which of the 8 study sites received heavy versus light grazing. The 58-year grazing period (i.e., 1948-2005) was not replicated in time, and the SRWMA elk herd $(n=2150$ elk) was not replicated in space. Unreplicated observational studies are appropriate if the statistical inferences drawn are limited to the particular study area (Wester 1992). Inferences from this study are limited to the needle and thread phase of the rough fescue/bluebunch wheatgrass habitat type in the Northern Rocky Mountains (Mueggler and Stewart 1980). Inferences can be extended beyond the SRMWA to other sites within the needle and thread phase of the rough fescue/ bluebunch wheatgrass habitat type because habitat type classification integrates the environmental effects on plant growth, reproduction, and competition so that all sites within the same habitat type phase exhibit the same trajectories of plant succession when subjected to similar disturbances (Daubenmire 1952, Hironaka et al. 1991). We used analysis of variance in the General Linear Model (GLM) procedure of SAS (Version 9.1; SAS Institute, Inc. 2004) to compare vegetation and soils between LG sites $(n=4)$ and HG sites $(n=4)$. Vegetation data from 2004 and 2005 were pooled because the study evaluated the cumulative effects of 58 years of grazing rather than a single-year response. Pooling also incorporated variability in weather between 2004 and 2005. The Univariate procedure of SAS (Version 9.1; SAS Institute, Inc.
2004) was used to test for normal distribution of residuals. Data that were not normally distributed were arcsine square-root transformed to stabilize variances and better approximate normal distribution of residuals (Kuehl 2000). For those variables whose normality was not satisfactorily improved by the arcsine squareroot transformation, the formula $\log \left(\sigma_{i}\right)=$ $\log (\alpha)+\beta \log \left(\mu_{i}\right)$ was used to empirically estimate the appropriate power transformation (Kuehl 2000). Means and standard errors presented in the text and table are from nontransformed data. Differences were considered significant at $P \leq 0.10$.

\section{RESULTS}

Every measure of foothills rough fescue plant vigor and productivity was lower in HG than in LG (Table 1). The most notable differences were in plant basal diameter $(69 \%$ smaller in $\mathrm{HG}$ ), species composition (3\% in HG vs. $38 \%$ in LG), and canopy cover (1\% in HG vs. $18 \%$ in LG).

Bluebunch wheatgrass plants had $43 \%$ fewer filled florets in HG than in LG, but canopy cover and species composition of bluebunch wheatgrass did not differ between LG and HG (Table 1). Idaho fescue leaf height was $28 \%$ less in HG than in LG, and Idaho fescue plants had 55\% fewer filled florets in HG than in LG (Table 1). However, canopy cover and species composition of Idaho fescue did not differ between LG and HG. Idaho fescue species composition averaged $7 \%$ in LG and HG.

Other than foothills rough fescue, dotted blazing star was the only plant species whose relative abundance differed between LG and HG. Dotted blazing star species composition was slightly greater in HG $5 \%$ in HG vs. $1 \%$ in LG). Common graminoids prairie junegrass, threadleaf sedge, and needle and thread averaged $8 \%, 7 \%$, and $2 \%$, respectively, in LG and HG.

Plant yield did not differ between LG and HG (Table 1). Herbaceous ground cover was $42 \%$ less in HG than in LG $(30 \%$ vs. $51 \%$, respectively), and clubmoss ground cover was dramatically greater in HG than in LG (Table 1). Ground cover of litter or bare ground did not differ between LG and HG.

Soil physical features (i.e., bulk density and thickness of the Ah horizon) differed in HG versus LG (Table 1). Soil bulk density was 
TABLE 1. Vegetation and soil characteristics of a foothills rough fescue grassland in west central Montana after longterm light or heavy grazing by elk during winter-early spring. Standard errors are in parentheses.

\begin{tabular}{|c|c|c|c|c|}
\hline \multirow[b]{2}{*}{ Response variable } & \multicolumn{4}{|c|}{ Long-term grazing intensity during winter-early spring } \\
\hline & Light & & Heavy & \\
\hline \multicolumn{5}{|l|}{ Foothills rough fescue } \\
\hline Leaf height $(\mathrm{cm})$ & $17.1(1.1) \mathrm{a}$ & $a^{a}$ & $11.9(1.1)$ & $\mathrm{b}$ \\
\hline Basal diameter $(\mathrm{cm})$ & $17.5(2.6)$ a & & $5.4(2.6)$ & $\mathrm{b}$ \\
\hline Filled florets $(\%)$ & $55.6(4.2)$ a & & $16.5(4.2)$ & $\mathrm{b}$ \\
\hline Canopy cover $(\%)$ & $17.7(4.2)$ a & & $0.6(4.2)$ & $\mathrm{b}$ \\
\hline Species composition $(\%)$ & $38.1(8.7)$ a & $\mathrm{a}$ & $2.7(8.7)$ & $\mathrm{b}$ \\
\hline \multicolumn{5}{|l|}{ Bluebunch wheatgrass } \\
\hline Leaf height $(\mathrm{cm})$ & $18.7(0.5)$ a & a & $18.0(0.5)$ & a \\
\hline Basal diameter $(\mathrm{cm})$ & $5.2(0.7)$ a & $\mathrm{a}$ & $6.1(0.7)$ & $\mathrm{a}$ \\
\hline Filled florets (\%) & $60.6(1.4) \mathrm{a}$ & $\mathrm{a}$ & $34.4(1.4)$ & $\mathrm{b}$ \\
\hline Canopy cover $(\%)$ & $3.1(2.0)$ a & $\mathrm{a}$ & $5.5(2.0)$ & $\mathrm{a}$ \\
\hline Species composition $(\%)$ & $7.0(5.8)$ a & $\mathrm{a}$ & $18.9(5.8)$ & $\mathrm{a}$ \\
\hline \multicolumn{5}{|l|}{ Idaho fescue } \\
\hline Leaf height (cm) & $7.2(0.2)$ a & $\mathrm{a}$ & $5.2(0.2)$ & $\mathrm{b}$ \\
\hline Basal diameter $(\mathrm{cm})$ & $6.8(0.8)$ a & $\mathrm{a}$ & $6.6(0.7)$ & $\mathrm{a}$ \\
\hline Filled florets $(\%)$ & $61.0(2.9) \mathrm{a}$ & $\mathrm{a}$ & $27.4(2.5)$ & $\mathrm{b}$ \\
\hline Canopy cover $(\%)$ & $3.7(0.9)$ a & $\mathrm{a}$ & $1.5(0.9)$ & $\mathrm{a}$ \\
\hline Species composition (\%) & $8.4(2.2)$ a & $\mathrm{a}$ & $5.6(2.2)$ & a \\
\hline \multicolumn{5}{|l|}{ Plant yield } \\
\hline Graminoids $\left(\mathrm{kg} \cdot \mathrm{ha}^{-1}\right)$ & $887(109) \mathrm{a}$ & & $602(109)$ & $\mathrm{a}$ \\
\hline Forbs $\left(\mathrm{kg} \cdot \mathrm{ha}^{-1}\right)$ & $410(57) \quad \mathrm{a}$ & $\mathrm{a}$ & $360(57)$ & $\mathrm{a}$ \\
\hline Total herbaceous $\left(\mathrm{kg} \cdot \mathrm{ha}^{-1}\right)$ & $1297(124) \mathrm{a}$ & $\mathrm{a}$ & $1024(124)$ & $\mathrm{a}$ \\
\hline \multicolumn{5}{|l|}{ Ground cover } \\
\hline Graminoids + forbs $(\%)$ & $50.7(5.0)$ a & $\mathrm{a}$ & $29.6(5.0)$ & $\mathrm{b}$ \\
\hline Clubmoss $(\%)$ & $0.2(9.0) \mathrm{a}$ & $\mathrm{a}$ & $31.2(9.0)$ & $\mathrm{b}$ \\
\hline Litter $(\%)$ & $32.9(5.7)$ a & a & $21.1(5.7)$ & $\mathrm{a}$ \\
\hline Bare ground (\%) & $6.5(4.1)$ a & $\mathrm{a}$ & $10.0(4.1)$ & $\mathrm{a}$ \\
\hline \multicolumn{5}{|l|}{ Soils } \\
\hline Bulk density $\left(\mathrm{g} \cdot \mathrm{cm}^{-3}\right)$ & $1.7(0.1)$ a & $\mathrm{a}$ & $2.0(0.1)$ & $\mathrm{b}$ \\
\hline Ah horizon thickness $(\mathrm{cm})$ & $10.0(0) \quad$ a & $\mathrm{a}$ & $8.0(0)$ & $\mathrm{b}$ \\
\hline Organic matter $(\%)$ & $4.3(0.2) \quad \mathrm{a}$ & $\mathrm{a}$ & $3.9(0.2)$ & $\mathrm{a}$ \\
\hline Carbon $(\%)$ & $3.6(0.2)$ a & $\mathrm{a}$ & $3.2(0.2)$ & $\mathrm{a}$ \\
\hline Nitrogen $(\%)$ & $0.3(0.0)$ a & $\mathrm{a}$ & $0.3(0)$ & $\mathrm{a}$ \\
\hline $\mathrm{C}: \mathrm{N}(\% \mathrm{C}: \% \mathrm{~N})$ & $10.6(0.2)$ a & $\mathrm{a}$ & $10.6(0.2)$ & $\mathrm{a}$ \\
\hline
\end{tabular}

${ }^{\mathrm{a}}$ Means in the same row followed by the same letter are not different $(P>0.10)$

greater in HG than in LG, and the Ah soil horizon was thinner in HG than in LG. However, all 4 soil nutrient metrics (i.e., soil OM, soil $\mathrm{C}$, soil $\mathrm{N}$, and C:N ratio) did not differ between LG and HG.

\section{Discussion}

We hypothesized that vegetation, ground cover, and soils of this foothills rough fescue grassland had been sustained by long-term LG but not HG during winter-early spring. Our results indicate that responses varied among plant and soil variables.

\section{Vegetation}

Consistent with our hypothesis, productivity of the dominant bunchgrass, foothills rough fescue, was lower in HG than in LG, and its species composition in LG compared favorably with relict sites of this habitat type phase (38\% in LG vs. 38\% in relict sites; Mueggler and Stewart 1980). Our results indicate that periodic rest from HG during winter-early spring is necessary to sustain foothills rough fescue, but the needed frequency of rest from grazing is unknown and warrants future research.

Bluebunch wheatgrass and Idaho fescue did not respond as hypothesized. Bluebunch wheatgrass and Idaho fescue were slightly less productive in HG than in LG, but their species composition percentages in our study sites were much lower than in relict sites of this habitat type phase. Bluebunch wheatgrass species composition averaged $13 \%$ in LG and HG 
sites compared with $26 \%$ in relict sites (Mueggler and Stewart 1980), whereas Idaho fescue species composition averaged $7 \%$ in LG and HG sites compared with $15 \%$ in relict sites (Mueggler and Stewart 1980). Apparently, both bluebunch wheatgrass and Idaho fescue did not tolerate long-term LG or HG during winter-early spring. Our results indicate that periodic rest from LG or HG during winter-early spring is necessary to sustain these bunchgrasses in foothills rough fescue grassland. The frequency of rest needed is unknown but is no more often than once every 4 years for bluebunch wheatgrass (Brewer et al. 2007).

Dotted blazing star is a desirable native forb that is palatable to livestock and wildlife (Johnson and Larson 1999), although Mueggler and Stewart (1980) rated its palatability to elk as poor. In our study, we attribute the increased abundance of dotted blazing star in HG compared with LG to the species' warmseason growth habit. Long-term HG by elk during winter-early spring likely favored dotted blazing star because its growing season did not begin until late spring-early summer, after the elk had migrated to higher elevations. Most other herbaceous plants in our foothills rough fescue grassland sites were cool-season plants that initiated growth in early spring while elk were present, making these plants more vulnerable to elk grazing than dotted blazing star.

Long-term HG in our study did not reduce herbaceous yield compared with LG. Our results differ from Willms et al. (1985) in southern Alberta, where long-term HG reduced herbaceous yield; however, Willms et al. (1985) studied long-term HG that occurred during late spring-summer-fall. Our results reaffirm that in foothills rough fescue grassland, defoliation during winter-early spring impacts plants less than defoliation that occurs later during the growing season (McLean and Tisdale 1972, Brewer et al. 2007).

\section{Ground Cover}

Herbaceous ground cover was less in HG than in LG, and clubmoss cover was greater in HG. These results were consistent with our hypothesis. Relative abundance of clubmoss generally increases on Montana rangeland when grazing pressure is excessive (Dolan and Taylor 1972). Our results suggest that herbaceous ground cover lost under HG during winter-early spring was replaced largely by clubmoss.

Bare ground and litter cover did not differ between HG and LG in our study, but they did differ when grazing occurred during late spring-summer-fall (Naeth et al. 1991, Bork et al. 2012). Our results indicate that bare ground and litter cover in foothills rough fescue grassland are impacted less by grazing during winter-early spring than by grazing later in the growing season.

\section{Soils}

Soil bulk density and the Ah horizon responded as hypothesized. Soil bulk density was $20 \%$ greater in HG than in LG, and the Ah horizon was $2 \mathrm{~cm}$ thinner in HG than in LG. Dormaar and Willms (1998) documented similar results when grazing occurred during late spring-summer-fall in southern Alberta. We did not detect winter-early spring grazing impacts to soil nutrient status. Johnson et al. (1971) reported similar results when grazing occurred during late spring-summer-fall, but Dormaar and Willms (1998) documented that soil C decreased as grazing pressure in late spring-summer-fall increased.

\section{Conclusions}

Grazing responses of the dominant perennial grasses in this foothills rough fescue grassland varied among species. Foothills rough fescue tolerated long-term LG during winter-early spring but not HG, whereas bluebunch wheatgrass and Idaho fescue did not tolerate either long-term LG or HG during winter-early spring. Periodic rest from HG during winter-early spring is necessary to sustain foothills rough fescue, and periodic rest from either LG or HG during winterearly spring is necessary to sustain bluebunch wheatgrass and Idaho fescue. Decreased productivity of foothills rough fescue in HG was accompanied by decreased herbaceous ground cover and increased abundance of the invasive dense clubmoss. Herbaceous yield and soil nutrient status (OM, C, N, C:N ratio) did not differ between HG and LG; however, soil bulk density was $18 \%$ greater in $\mathrm{HG}$, and the Ah horizon was $20 \%$ thinner in HG. We conclude that long-term elk grazing during winter-early spring degraded the vegetation, ground cover, 
and soils of this foothills rough fescue grassland. Our results add to the small but growing body of literature that documents wild ungulate overgrazing effects on soils and herbaceous vegetation in western North America (Zeigenfuss et al. 2002, Best and Bork 2003, Binkley et al. 2003, Rexroad et al. 2007, Gass and Binkley 2011).

\section{ACKNOWLEDGMENTS}

We gratefully acknowledge Josh Bilbao, Stephanie Keep, Merrita Fraker-Marble, Heidi Crum, Brent Roeder, Jamie Saxton, Stephanie Sever, and Brian Thrift for assistance with field sampling. We also thank Quentin Kujala and Graham Taylor of Montana Fish, Wildlife and Parks for their interest in this project; Jon Siddoway of the USDA Natural Resources Conservation Service for assistance with ecological site descriptions; and Rachel Frost for assistance with statistical analyses. Research was funded by the USDA Joe Skeen Institute for Rangeland Restoration and the Montana Agricultural Experiment Station.

\section{Literature Cited}

AOAC. 1997. Official methods of analysis. 16th edition. Association of Official Analytical Chemists, Arlington, VA.

Bailey, A.W., And C.E. Poulton. 1968. Plant communities and environmental relationships in a portion of the Tillamook Burn, northwestern Oregon. Ecology 49:1-13.

Best, J.N., AND E.W. BorK. 2003. Using transplanted plains rough fescue (Festuca hallii [Vasey] Piper) as an indicator of grazing in Elk Island National Park, Canada. Natural Areas Journal 23:202-209.

Binkley, D., F. Singer, M. Kaye, and R. Rochelle. 2003. Influence of elk grazing on soil properties in Rocky Mountain National Park. Forest Ecology and Management 185:239-247.

Blake, G.R., AND K.H. Hartge. 1986. Bulk density. Pages 363-375 in A. Klute, editor, Methods of soil analysis. Part 1: physical and mineralogical methods. American Society of Agronomy Monograph Number 9, Madison, WI

Bork, E., W. Willms, S. Tannas, and M. Alexander. 2012. Seasonal patterns of forage availability in the fescue grasslands under contrasting grazing histories. Rangeland Ecology and Management 65:47-55.

Brewer, T.K., J.C. Mosley, D.L. LuCAS, AND L.R. SCHMIDT 2007. Bluebunch wheatgrass response to spring defoliation on foothill rangeland. Rangeland Ecology and Management 60:498-507.

Cochran, W.G. 1983. Planning and analysis of observational studies. John Wiley \& Sons, New York, NY.

Cook, C.W., AND J. Stubbendieck. 1986. Range research: basic problems and techniques. Society for Range Management, Denver, CO.
Daubenmire, R.F. 1952. Forest vegetation of northern Idaho and adjacent Washington, and its bearing on concepts of vegetation classification. Ecological Monographs 22:301-330.

1959. A canopy-coverage method of vegetational analysis. Northwest Science 33:43-64.

Dolan, J.J., AND J.E. TaYlor. 1972. Residual effects of range renovation on dense clubmoss and associated vegetation. Journal of Range Management 25: 32-37.

DoRMaAR, J.F., AND W.D. WiLLMS. 1990. Sustainable production from the rough fescue prairie. Journal of Soil and Water Conservation 45:137-140.

1998. Effect of forty-four years of grazing on fescue grassland soils. Journal of Range Management 51:122-126.

Eberhardt, L.L., and J.M. Thomas. 1991. Designing environmental studies. Ecological Monographs 61: $53-73$.

FryxelL, F.M. 1928. The former range of the bison in the Rocky Mountains. Journal of Mammalogy 9: 129-139.

Gass, T.M., AND D. Binkley. 2011. Soil nutrient losses in an altered ecosystem are associated with native ungulate grazing. Journal of Applied Ecology 48: 952-960.

Hironaka, M., M.A. Fosberg, and K.E. Neiman Jr. 1991. The relationship between soils and vegetation. Pages 29-31 in A.E. Harvey and L.F. Neuenschwander, editors, Proceedings, management and productivity of western-montane forest and soils symposium. General Technical Report INT-280, USDA Forest Service, Intermountain Research Station, Ogden, UT.

Johnson, J., AND G.E. LaRson. 1999. Grassland plants of South Dakota and the Northern Great Plains. South Dakota State University Agricultural Experiment Station Bulletin B566, Brookings, SD.

Johnston, A., J.F. DoRmaAR, AND S. SMOLIAK. 1971. Longterm grazing effects on fescue grassland soils. Journal of Range Management 24:185-188.

Johnston, A., AND M.D. MACDonalD. 1967. Floral initiation and seed production in Festuca scabrella Torr. Canadian Journal of Plant Science 47:577-583.

Jourdonnais, C., And D.J. Bedunah. 1990. Prescribed fire and cattle grazing on an elk winter range in Montana. Wildlife Society Bulletin 18:232-240.

KNight, R.R. 1970. The Sun River Elk Herd. Wildlife Monographs 23:4-66.

KuenL, R.O. 2000. Design of experiments: statistical principles of research design and analysis. 2nd edition. Duxberry Press, Pacific Grove, CA.

Looman, J. 1969. The fescue grasslands of western Canada. Vegetatio 19:128-145.

MCLean, A., AND E.W. Tisdale. 1972. Recovery rate of depleted range sites under protection from grazing. Journal of Range Management 25:178-184.

MCLEAN, A., AND S. WIKEEM. 1985a. Influence of season and intensity of defoliation on bluebunch wheatgrass survival and vigor in British Columbia. Journal of Range Management 38:21-26.

1985b. Rough fescue response to season and intensity of defoliation. Journal of Range Management 38:100-103.

Moss, E.H., AND J.A. Campbell. 1947. The fescue grassland of Alberta. Canadian Journal of Research 25c: 209-227. 
MueggLeR, W.F. 1975. Rate and pattern of vigor recovery in Idaho fescue and bluebunch wheatgrass. Journal of Range Management 28:198-204.

Mueggler, W.F., and W.L. SteWART. 1980. Grassland and shrubland habitat types of western Montana. General Technical Report INT-66, USDA Forest Service, Intermountain Forest and Range Experiment Station, Ogden, UT.

Naeth, M.A., A.W. Bailey, D.J. Pluth, D.S. Chanasyk, AND R.T. HaRdin. 1991. Grazing impacts on litter and soil organic matter in mixed prairie and fescue grassland ecosystems of Alberta. Journal of Range Management 44:7-12.

Nelson, D.W., AND L.E. Sommers. 1982. Total carbon, organic carbon and organic matter. Pages 539-579 in A.L. Page, editor, Methods of soil analysis. Part 2: chemical and microbiological properties. American Society of Agronomy Monograph Number 9, Madison, WI.

Patton, B.D., M. Hironaka, and S.C. Bunting. 1988. Effect of burning on seed production of bluebunch wheatgrass, Idaho fescue, and Columbia needlegrass. Journal of Range Management 41:232-234.

Picton, H.D., AND I.E. Picton. 1975. Saga of the Sun, a history of the Sun River Elk Herd. Game Management Division, Montana Fish and Game Department, Helena, MT.

Rexroad, E.A., K.H. Beard, and A. Kulmatiski. 2007. Vegetation responses to 35 and 55 years of native ungulate grazing in shrubsteppe. Western North American Naturalist 67:16-25.

SAS InstituTe, InC. 2004. SAS version 9.1 user's guide. SAS Institute, Inc., Carey, NC.

TisDaLE, E.W. 1947. The grasslands of the southern interior of British Columbia. Ecology 28:346-382.

[USDA-FS] United States Department of AgricultureForest Service. 1937. Range plant handbook. U.S. Government Printing Office, Washington, DC.

[USDA-NRCS] United States Department of Agriculture-Natural Resources Conservation Service.
2003. Soil Data Mart: Lewis and Clark County, Montana, Beanlake-Winspect Stony Loam, 543-D. [Cited 6 October 2003]. Available from: http://soil datamart.nrcs.usda.gov/.

. In press. Limy 13-19 inches mean annual precipitation ecological site description, Northern Rocky Mountain Foothills, North, Montana Technical Guide, Bozeman, MT.

[USDA and USDI] United States Department of Agriculture and United States Department of INTERIOR. 1996. Utilization studies and residual measurements. Interagency Technical Reference BLM/RS/ST96/004+1730. Bureau of Land Management, Denver, CO.

Wester, D.B. 1992. Viewpoint: replication, randomization, and statistics in range research. Journal of Range Management 45:285-290.

Western Regional Climate Center. 2005. Augusta, MT (240364). [Cited 10 October 2005]. Available at: http://www.wrcc.dri.edu/.

WiLLMS, W.D. 1991. Cutting frequency and cutting height effects on rough fescue and Parry oat grass yields. Journal of Range Management 44:82-86.

Willms, W.D., J.F. Dormaar, and G.B. Schaalje. 1988. Stability of grazed patches on rough fescue grasslands. Journal of Range Management 41:503-508.

WiLLms, W.D., AND D.A. QuinTon. 1995. Grazing effects on germinable seeds on the fescue prairie. Journal of Range Management 48:423-430.

Willms, W.D., S. Smoliak, and J.F. Dormaar. 1985. Effects of stocking rate on rough fescue grassland vegetation. Journal of Range Management 38: 220-225.

Zeigenfuss, L.C., F.J. Singer, S.A. Williams, and T.L. JOHNSON. 2002. Influences of herbivory and water on willow in elk winter range. Journal of Wildlife Management 66:788-795.

Received 24 December 2012 Accepted 12 September 2013 